\title{
Information Needs and Seeking Behaviour of Senior Non- Academic Staff In Nigerian Universities
}

\author{
${ }^{1}$ Madukoma, Ezinwanyi PhD, ${ }^{2}$ Prof. Opeke, Roseline O. \\ ${ }^{1}$ Department of Information Resources Management Babcock Business School Babcock University Ilishan- \\ Remo, Ogun State Nigeria \\ ${ }^{2}$ Department of Information Resources Management Babcock Business School Babcock University \\ Ilishan-Remo, Ogun State Nigeria
}

\begin{abstract}
This study investigated the information needs and seeking behaviour of senior non-academic staff in selected universities in Nigeria. Whereas a lot has been written about teaching staff in universities, little is known through literature about the information needs and seeking behaviour of senior non-academic of Nigerian universities. The study adopted the survey research design. The population was made up of 1,804 senior non-academic staff from 27 universities in Nigeria. 1,270 senior non-academic staff was selected for the sample. Descriptive statistics was use to analyze the data collected. The study established among others, that senior non-academic staff had varied information needs based on their work roles; they sought information mainly for decision making; and availability of information source largely influenced their information source selection. The study also found that senior non-academic staff in Nigerian universities contacted first subordinates in the office when seeking information on a crucial issue, while task complexity motivated them to seek information. Hence inadequate information retrieval techniques/skills, inadequate time to seek information and lack of awareness about where to obtain information were the major challenges senior non-academic faced in the course of seeking information to perform their works. The study therefore recommends that librarians/information managers should ensure that regular information literacy program, current awareness servicesand selective dissemination of information are provided to senior non-academic staff to enable them have easy and regular access to timely information for more productivity output.
\end{abstract}

Keywords: Information needs, seeking behaviour, senior non-academic staff, Nigerian Universities.

\section{Introduction}

Information is important in every organization. It has been established through various literature that good and quality information can improve decision making, enhance efficiency and allow organizations to gain competitive advantages. Popoola (2006) defined information as facts, opinions, messages, symbols, and processed data that are capable of improving the knowledge state of a user on a random phenomenon. Therefore, to function properly in a rapidly changing academic environment, senior non-academic staff need to interact with variety of information notwithstanding that factors that affect information seeking are getting more complex and dynamic by the day. In seeking for information, it is necessary to have complete and recent information about things and circumstances as possible. Studies on information needs and seeking acknowledge that work related tasks necessitate information use and work related information enhances job productivity. Rad, Shams and Naderi (2009) attest that managers need quality information to help them make decisions, achieve organizational goals and objectives, and improve services and productivity; and they believe that in performing tasks, different managers would require different information. Moreover, managers seek information to perform various tasks and will need and seek various types of information resources to perform their work.

In the same vein, senior non-academic staff occupies different position and play different roles in the universities; they will need and seek information inherent to their jobs. According to Smerek and Peterson (2007), non-academic staff members are key components in today's higher education settings. They are responsible for the day-to-day operations of a university. The non-academic staff performs mainly administrative, as well as technical duties. They are made up of the following divisions within the university: The Registry, Maintenance, Vice Chancellor's Office, Deputy Vice Chancellor's Office, Bursary, Grounds, Student Affairs, Human Resources/Establishment, Cafeteria, Security, Venture, Bookshop, among others. Therefore, senior non-academic staff needs information to carry out their duties. Hence, little is known about the way senior non-academic staff identifies their information needs and seek information to perform their work.

It is in this line that this study investigated the information needs and seeking behaviour of senior nonacademic staff in Nigerian universities. Therefore, the study specifically sought to:

1. Determine the information needs of senior non-academic staff in Nigerian universities; 
2. Explore the information seeking behaviour of senior non-academic staff in Nigerian universities;

3. Find out the challenges faced by senior non-academic staff in Nigerian universities while seeking information.

\section{Hypothesis}

There is no significant difference in information needs of senior non-academic staff in the various types of universities (federal, state and private) in Nigerian.

\section{Literature Review}

Nigerian universities are expected to make optimum contributions to national development through training of high level manpower. This can adequately be achieved when members, including the non-academic staff of the university, are involved in all aspects, as the entire staff have prominent role to play as they are in regular contact with one another, the students, parents and in some cases, with external bodies. Relevant information is therefore needed by all categories of people, including the non-academic staff for effective delivery of services. It has been established that information is a vital resource to all professions, though the information needs of various professionals vary (Gbadamosi, 2005).

According to Kuhlthau (1994), information need is stemming from a vague awareness of something missing and as culminating in locating information that contributes to understanding and meaning. To Belkin, Brooks and Oddy (1982), information need is an anomalous state of knowledge, or a gap in individual's knowledge in sense making situation (Dervin and Nilan, 1986). Similarly, Ikoja-Odongo and Mostert (2006) attest that information need is a requirement that drives people to seek information. Thus, information needs stimulates from a lack in knowledge data or inadequacy to satisfy a goal or objective. Information need in today's society cannot be overemphasized as there is a little possibility of taking wise decision without information.

Alwis, Majid and Chadhry (2006) cited in Yan and Davison (2011) established that managers/supervisors' information need is associated with the immediate business or task environment to guide their operational decision making. This is applicable to senior non-academic staff of the universities. They also need information associated with their immediate and external work environment in order to meet the expected target. In the same view, Bassey and Akpan (2010) note that university managers like all other managers in different sectors of the economy have a set of roles to perform, if predetermined objectives of the university should be attained. Some of these roles include preparation and defining of budgets, attracting financial support to the institution, management of human and material resources of the institution, coaching and training of staff, among others.

Wilkins and Leckie (1997) established that professional and managerial staff basic information need were professional literature, internal university information and regulations, technical literature/manuals, general management literature and government regulations; furthermore, Bradley (2009) found out that in her study that the type of information needed by the non-academic staff were internal university information, information from other universities (best practices from other universities), news/current events information, and professional literature/current developments in their fields. This implies that senior non-academic staff, based on their work role are likely to have the above mentioned information needs.

Jarvelin and Wilson (2003) however identified three types of information needed in tasks performance namely, problem information (PI), domain information (DI) and problem solving information (PSI). These three categories of information they expressed are orthogonal, that is, they represent three different dimensions and have different roles in problem treatment. All are necessary in problem treatment but, depending on the task, and to different degrees, may be available to a worker performing the task. Because their typical sources are different, typical channels for acquiring them may also differ. Moreover, information sources are an increasingly important part of all organizations activities. For this reason, workers should seek and use information in order to achieve the organizational goals which in the course of seeking may differ.

According to $\mathrm{Wu}$ (2011), information seeking involves searching for, extracting, and using information for a specific purpose when a person does not have sufficient prior knowledge. Patitungkho and Deshpande (2005) and Bhatti (2009) iterate that information seeking behaviour is expressed in various forms, from reading printed materials to research and experimentation. Popoola (2006) opined that managers monitor and evaluate trends in their business environment through internal and external channels of information available and accessible to them. Also, Almutairi (2011) reported that younger managers (under the age 40) use social activities as information sources more often and they find subordinates and peers more useful than older mangers do; male managers also use subordinates as information sources more frequently than female managers do.

However, Bystrom (2006) argued that when a task is perceived to be more complex, people tend to rely on experts as a source of information. Moreover, individuals can seek information from a variety of sources, and 
these sources convey information in a variety of ways. These include personal sources of information which include peers, direct supervisors, and experienced coworkers, superiors other than their direct supervisor, subordinates, support personnel, and individuals external to the organization; friends and colleagues, books and online sources and do not necessarily depend on a single source. Prior research according to Fiedleer, Lash, Wong and Tiainen (2006) and Agarwal, Xu and Poo (2011) indicates that experienced peers and direct supervisors are the most frequently accessed sources of information.Apparently, instant access to information from multiple sources facilitates information utilization for improved productivity and decision making of senior non-academic staff. Agarwal, Xu and Poo (2011) believe that it is important to have the knowledge of how a person seeks information in an organizational setting. It can help to ensure that employees have easy and unhindered access to their preferred information sources in carrying out their day-to-day tasks. However, Tackie and Adams (2007) posit that the factors that affect information seeking are getting more complex and dynamic by the day. In similar way, Pettigrew (1996) attest that barriers that prevent individuals from seeking and getting information are also of great importance in understanding the information seeking behavior of individuals and organizations.

\section{Methodology}

A descriptive survey research design was adopted for the study. The study population comprised 112 approved universities in Nigeria by National Universities Commission (NUC, 2011). Multistage sampling technique was used to select 27 universitiesthat participated in the study while 1804 senior non-academic staff was randomly selected as the sample size for the study.A structured questionnaire was the instrument used for data collection. Data was analyzed using descriptive statistics, mean and standard deviation while regression was used to analyze the hypothesis.

\section{Results and Interpretation}

The result indicated that 1270 participants were involved in this study, out of which those that were between 20 to 30 years was $8.7 \%$; those between 31 to 40 years was $45.4 \%$; those between 41 to 50 was $42.1 \%$ and those that were above 50 years $3.8 \%$. This implies that majority of the participants were between 31 to 50 years, indicating that the workforce tend to be relatively young.

Table 1: Distribution of the Respondents Based on Gender

\begin{tabular}{|l|c|l|}
\hline Gender & F & \% \\
\hline Male Respondents & 565 & 44.5 \\
\hline Female Respondents & 705 & 55.5 \\
\hline Total & $\mathbf{1 2 7 0}$ & $\mathbf{1 0 0 . 0}$ \\
\hline
\end{tabular}

Table 1, revealed that there were more female participants (55.5\%) than male participants (44.5\%) in the study. This result could mean that senior non-academic staff were more of female in most universities in Nigeria, or it could as well be that female respondents were willing and more open to respond to the questionnaire than their male counterparts.

In the attempt to establish the information needs of senior non-academic staff in Nigerian universities, the respondents were given options to rate their information needs. This is presented in table 2 .

Table 2: Information Needs of Senior Non-academic Staff Members of Nigerian University

\begin{tabular}{|c|l|c|c|c|c|c|c|}
\hline S/N & \multicolumn{1}{|c|}{ STATEMENT } & VI & I & SI & NI & MEAN & STD.D \\
\hline 1 & Professional information & $\begin{array}{c}593 \\
(46.7)\end{array}$ & $\begin{array}{c}269 \\
(21.1)\end{array}$ & $\begin{array}{c}242 \\
(19.1)\end{array}$ & $\begin{array}{c}164 \\
(12.9)\end{array}$ & 3.01 & 1.09 \\
\hline 2 & International university & $\begin{array}{c}319 \\
\text { information }\end{array}$ & $\begin{array}{c}587 \\
(25.2)\end{array}$ & $\begin{array}{c}299 \\
(46.1)\end{array}$ & $\begin{array}{c}63 \\
(23.6)\end{array}$ & 2.91 & .83 \\
\hline 3 & Information on & 361 & 530 & 285 & 92 & 2.91 & .90 \\
& youth/juvenile & $(28.4)$ & $(41.7)$ & $(22.5)$ & $(7.3)$ & & \\
\hline 4 & General management & 404 & 406 & 354 & 106 & 2.87 & .96 \\
& information & $(31.7)$ & $(32.0)$ & $(27.9)$ & $(8.4)$ & & \\
\hline 5 & External university & 365 & 477 & 295 & 133 & 2.85 & .96 \\
& $\begin{array}{l}\text { information for competitive } \\
\text { advantage }\end{array}$ & $\begin{array}{c}(28.8) \\
(37.4)\end{array}$ & $(23.3)$ & $(10.5)$ & & \\
\hline 6 & Development information & $\begin{array}{c}464 \\
(36.4)\end{array}$ & $\begin{array}{c}351 \\
(27.7)\end{array}$ & $\begin{array}{c}239 \\
(18.9)\end{array}$ & $\begin{array}{c}211 \\
(16.7)\end{array}$ & 2.83 & 1.11 \\
\hline 7 & Government regulations & $\begin{array}{c}376 \\
(29.6)\end{array}$ & $\begin{array}{c}373 \\
(29.4)\end{array}$ & $\begin{array}{c}414 \\
(32.6)\end{array}$ & $\begin{array}{c}103 \\
(6.1)\end{array}$ & 2.80 & .97 \\
& information & & & & & \\
\hline
\end{tabular}




\begin{tabular}{|c|c|c|c|c|c|c|c|}
\hline 8 & Job related information & $\begin{array}{c}474 \\
(37.2)\end{array}$ & $\begin{array}{c}265 \\
(20.9)\end{array}$ & $\begin{array}{c}329 \\
(26.0)\end{array}$ & $\begin{array}{c}197 \\
(15.5)\end{array}$ & 2.79 & 1.12 \\
\hline 9 & Technical information & $\begin{array}{l}274 \\
(21.5)\end{array}$ & $\begin{array}{c}585 \\
(46.0)\end{array}$ & $\begin{array}{c}265 \\
(20.9)\end{array}$ & $\begin{array}{l}146 \\
(11.5)\end{array}$ & 2.78 & .91 \\
\hline 10 & Legal information & $\begin{array}{c}318 \\
(25.1)\end{array}$ & $\begin{array}{c}461 \\
(36.1)\end{array}$ & $\begin{array}{c}370 \\
(29.2)\end{array}$ & $\begin{array}{l}117 \\
(9.2)\end{array}$ & 2.76 & .94 \\
\hline 11 & $\begin{array}{l}\text { Financial management } \\
\text { information }\end{array}$ & $\begin{array}{c}359 \\
(28.3) \\
\end{array}$ & $\begin{array}{c}429 \\
(33.8) \\
\end{array}$ & $\begin{array}{c}290 \\
(22.8) \\
\end{array}$ & $\begin{array}{c}188 \\
(14.8) \\
\end{array}$ & 2.75 & 1.03 \\
\hline 12 & Religious information & $\begin{array}{c}399 \\
(31.3) \\
\end{array}$ & $\begin{array}{c}353 \\
(27.8) \\
\end{array}$ & $\begin{array}{c}311 \\
(24.5) \\
\end{array}$ & $\begin{array}{c}203 \\
(16.0) \\
\end{array}$ & 2.74 & 1.08 \\
\hline 13 & Supplier information & $\begin{array}{c}338 \\
(26.6)\end{array}$ & $\begin{array}{c}460 \\
(36.1)\end{array}$ & $\begin{array}{c}294 \\
(23.2)\end{array}$ & $\begin{array}{l}120 \\
(9.5)\end{array}$ & 2.71 & 1.10 \\
\hline 14 & $\begin{array}{l}\text { Report of organizational } \\
\text { performance }\end{array}$ & $\begin{array}{c}327 \\
(25.7)\end{array}$ & $\begin{array}{c}431 \\
(33.9)\end{array}$ & $\begin{array}{c}325 \\
(25.6)\end{array}$ & $\begin{array}{c}166 \\
(13.1)\end{array}$ & 2.69 & 1.05 \\
\hline 15 & External statistics & $\begin{array}{l}270 \\
(21.3)\end{array}$ & $\begin{array}{c}433 \\
(33.9)\end{array}$ & $\begin{array}{c}467 \\
(36.9)\end{array}$ & $\begin{array}{c}96 \\
(7.6)\end{array}$ & 2.68 & .90 \\
\hline 16 & Motivational information & $\begin{array}{c}323 \\
(25.3)\end{array}$ & $\begin{array}{c}445 \\
(35.0)\end{array}$ & $\begin{array}{c}267 \\
(21.1)\end{array}$ & $\begin{array}{c}231 \\
(18.2)\end{array}$ & 2.67 & 1.05 \\
\hline 17 & Parenting information & $\begin{array}{c}327 \\
(25.8)\end{array}$ & $\begin{array}{c}419 \\
(32.8)\end{array}$ & $\begin{array}{c}287 \\
(22.7)\end{array}$ & $\begin{array}{c}233 \\
(18.4)\end{array}$ & 2.65 & 1.06 \\
\hline 18 & Educational information & $\begin{array}{c}391 \\
(30.7) \\
\end{array}$ & $\begin{array}{c}378 \\
(29.8)\end{array}$ & $\begin{array}{c}174 \\
(13.7) \\
\end{array}$ & $\begin{array}{c}323 \\
(25.5) \\
\end{array}$ & 2.65 & 1.17 \\
\hline 19 & Socio-cultural information & $\begin{array}{c}300 \\
(23.7)\end{array}$ & $\begin{array}{c}361 \\
(28.3)\end{array}$ & $\begin{array}{c}388 \\
(30.5)\end{array}$ & $\begin{array}{c}206 \\
(16.3)\end{array}$ & 2.57 & 1.06 \\
\hline 20 & Economic information & $\begin{array}{c}281 \\
(22.2)\end{array}$ & $\begin{array}{c}345 \\
(27.2)\end{array}$ & $\begin{array}{c}384 \\
(30.3)\end{array}$ & $\begin{array}{c}235 \\
(18.5)\end{array}$ & 2.50 & 1.08 \\
\hline 21 & Marketing information & $\begin{array}{c}278 \\
(21.9)\end{array}$ & $\begin{array}{c}445 \\
(35.0)\end{array}$ & $\begin{array}{c}387 \\
(30.5)\end{array}$ & $\begin{array}{c}156 \\
(12.3)\end{array}$ & 2.66 & .96 \\
\hline
\end{tabular}

KEY: VI is Very Important; I is Important; SI is slightly Important and NI is Not Important.

The result on table 2 reveals that senior non-academics staff members have varied information needs rangingfrom professional information with $($ mean $=3.01)$; internal university information $($ mean $=2.91)$; information on youths/juvenile $($ mean $=2.91)$; general management information $($ mean $=2.87)$; external university information for competitive advantage $($ mean $=2.85)$; development information $($ mean $=2.83$ ); government regulation information $($ mean $=2.80)$; job related information (mean $=2.79$ ) among others. The reason for variation in their information needs may be as a result of type/level of the job roles and managerial positions. This implies that as their work roles vary, so will their information need.

This finding is in line with that of Wilkins and Leckie (1997) and Bradley in their study of information needs and seeking patterns of university professional and managerial staff. They discovered that the respondents' information needs varied ranging from information on professional literature, internal university information, suppliers' information and general management information. Also, Alwis, Majid and Chaudhry (2006) cited in Yan and Davison (2011), stressed that managers information behaviour reflects a relationship with their work settings and information environment which highlights a need to understand problem situations as a precursor to understanding how to seek and use information. From the foregoing, one would conclude that senior non-academic staff of Nigerian Universities generally needs information based on their different tasks/roles.

Table 3: Information Seeking Behaviour of Senior Non-academic Staff Members of Nigerian Universities

\begin{tabular}{|c|l|l|c|c|}
\hline S/N & \multicolumn{1}{|c|}{ RESPONSE OPTION } & F & \% \\
\hline 1 & In what area of your work do & Decision making & 435 & 34.3 \\
& you actively seek information & Planning & 248 & 19.5 \\
& most? & Organizing & 198 & 15.6 \\
& & Controlling & 179 & 14.1 \\
& & Coordinating & 146 & 11.5 \\
& & Directing & 44 & 3.5 \\
& & No response & 20 & 1.6 \\
\hline
\end{tabular}




\begin{tabular}{|c|c|c|c|c|}
\hline 2 & $\begin{array}{c}\text { What factors largely influence } \\
\text { your sources selection? }\end{array}$ & $\begin{array}{l}\text { Availability of sources } \\
\text { Awareness of sources existence } \\
\text { Quality of sources } \\
\text { Relevance of sources } \\
\text { Reliability of sources } \\
\text { Ease of access to sources } \\
\text { No response }\end{array}$ & $\begin{array}{c}389 \\
362 \\
173 \\
161 \\
160 \\
24 \\
1\end{array}$ & $\begin{array}{l}30.7 \\
28.5 \\
13.6 \\
12.7 \\
12.6 \\
1.9 \\
.1\end{array}$ \\
\hline 3 & $\begin{array}{c}\text { On a crucial issue, who is your } \\
1^{\text {st }} \text { contact when seeking } \\
\text { information }\end{array}$ & $\begin{array}{l}\text { Subordinate in the office } \\
\text { Library } \\
\text { Print materials } \\
\text { Policy paper } \\
\text { Colleagues in my office } \\
\text { Superiors in my office } \\
\text { Colleagues outside the office } \\
\text { No response }\end{array}$ & $\begin{array}{r}343 \\
263 \\
221 \\
204 \\
199 \\
30 \\
6 \\
1\end{array}$ & $\begin{array}{c}27.1 \\
20.8 \\
17.4 \\
16.1 \\
15.7 \\
2.4 \\
.5 \\
.1\end{array}$ \\
\hline 4 & $\begin{array}{l}\text { What motivates your } \\
\text { information seeking? }\end{array}$ & $\begin{array}{l}\text { Task complexity } \\
\text { More productive } \\
\text { Innovation and creativity } \\
\text { To know more } \\
\text { To enhance efficiency and effectiveness } \\
\text { Skill acquisition } \\
\text { No response }\end{array}$ & $\begin{array}{c}300 \\
294 \\
266 \\
189 \\
180 \\
40 \\
1\end{array}$ & $\begin{array}{c}23.7 \\
23.2 \\
20.9 \\
14.8 \\
14.1 \\
3.2 \\
.1\end{array}$ \\
\hline 5 & $\begin{array}{l}\text { How much time do you devote } \\
\text { to active information searching } \\
\text { in a week? }\end{array}$ & $\begin{array}{l}\text { Between } 1-3 \text { hours } \\
\text { As the need arises } \\
7-9 \text { hours } \\
4-6 \text { hours } \\
10 \text { hours or more } \\
\text { No response }\end{array}$ & $\begin{array}{c}345 \\
326 \\
215 \\
213 \\
149 \\
22\end{array}$ & $\begin{array}{c}27.2 \\
25.7 \\
16.9 \\
16.8 \\
11.7 \\
1.7\end{array}$ \\
\hline 6 & $\begin{array}{l}\text { Which of the following sources } \\
\text { do you spend time seeking? }\end{array}$ & $\begin{array}{l}\text { Library } \\
\text { Print materials } \\
\text { Superior in the office } \\
\text { Policy paper } \\
\text { Colleagues in my office } \\
\text { Subordinate in my office }\end{array}$ & $\begin{array}{l}352 \\
293 \\
285 \\
154 \\
113 \\
73\end{array}$ & $\begin{array}{c}27.7 \\
23.1 \\
22.4 \\
12.1 \\
8.9 \\
5.8\end{array}$ \\
\hline
\end{tabular}

In order to find answers to information seeking behaviour of senior non-academic staff in Nigerian universities, the respondents were asked to choose from the options made available to them. This is shown on table 3 .

The information seeking behaviour of the senior non-academic staff members of Nigeria universities reveals that about $34.3 \%$ of the respondents actively sought information on decision making activities in their jobs; $19.5 \%$ actively sought information about planning their jobs; $15.6 \%$ sought information on organizing; $14 \%$ seek information on how to control; $11.5 \%$ sought information on coordination; while only $3.5 \%$ sought information on directing. This response shows that senior non-academic staff in Nigerian universities actively seeks information for their job activities. This implies that there is likelihood of effective and efficient decision making process and other activities they perform. This finding corroborates with that of Rad, Shams and Naderi (2009) who attest that managers need quality information to help them makedecisions, achieve organizational goals and objectives, and improve services and productivity.

The result on Table 3 also established that availability of sources of information influences about $30.7 \%$ of the respondents to seek information; awareness of sources influences (28.7\%); while quality of sources influences (13.6\%). Relevance of sources influences (12.7\%), and reliability of sources influences $(12.6 \%)$. Ease of access to sources (1.9\%) does not feature prominently in the source selection equation, although admittedly it plays an important part too.This implies that for senior non-academic staff in Nigerian universities, information source availability and awareness of sources were the major factors of their source selection. Quality of sources, relevance of sources, and reliability of sources were not found to be crucial. Ease of access was found to be the least important. This is a rather worrisome finding because it suggests that respondents do not see source reliability, quality and relevance as important conditions for selecting a piece of information as long as the information is available. This finding disagrees with that of Bradley (2009) who found out in her study that accuracy (83.8) and quality (69.6\%) of information was the major factors that influence source selection. Also, Agarwal, Poo, and Xu (2011) established in their study that quality and access are important antecedents of sources used regardless of the source type. This has important implication for the decision making activities of senior non-academic staff in Nigerian universities. 
The same table shows that $27 \%$ of the senior non-academic staff will contact subordinates in their office first when seeking for information, $20.8 \%$ will contact the library first on a crucial issue; $17.4 \%$ will first contact print materials; $16 \%$ will contact policy paper first and $15.7 \%$ will first contact colleagues in their offices. Furthermore, some contact superiors in their offices $(2.4 \%)$ and colleagues outside the offices $(.5 \%)$ were the least contacts. This finding may not be surprising as it has been established earlier in this work that senior non-academic staff's information need varies. This could be attributed to the fact that each worker will seek information from which ever source that would solve his/her information need and one is expected to seek for information from varied sources. Further, literature has established that people always consult first, those closest to them and that they often prefer face-to-face sources. Thus proximity is a factor in information seeking of senior non-academic staff in Nigerian universities. This corresponds with the findings of Fiedler, Lash, Wong and Tiainen (2006); Argawal, Xu and Poo (2011), who attest that people get information from multiple sources such as friends and colleagues, books, online sources, among others. Similarly, Popoola (2006) affirmed that managers monitor and evaluate trends in their business environment through internal channels of information available and accessible to them.

On the same Table 3, the respondents were asked what motivates their information seeking and they were requested to select from the available options. To the respondents, complexity of task was the major factor that motivates them to seek information (23.7\%). This was closely followed with $21 \%$ who indicated that to be more productive motivates their information seeking, innovative and creativity ability motivates $20.9 \%$ to seek for information. This was distantly followed by $14.8 \%$ that indicated that to know more, motivates their information seeking; while $14.1 \%$ were motivated by enhancing efficiency and effectiveness, and skill acquisition $(3.2 \%)$. Going by the finding of this study, majority of the respondents have strong peck for information seeking for task complexity, to be more productive, and innovation and creativity. Thus, this will bring productive and value added output to the organization as a whole. This finding is in line with PezeshkiRad and Zamani (2005) who established that complex task requires several of information seeking process. Goldstone, Roberts and Gureckis (2008) also believed that information internalized enhances innovation and creativity to productive behaviour that employees exhibit when performing their jobs in achieving the organizational objectives.

Indication from table 3 also reveals that $27 . \%$ of the senior non-academic spend between 1 to 3 hours in a week to seek information; $25.7 \%$ seek information as the need arises, $16.9 \%$ spend between 7 to 9 hours; $16.8 \%$ spend between 4 to 6 hours; $11 \%$ spend above 10 hours and above to seek for information in a week. The disparity in time spent in seeking information could be attributed to the availability of individual free time to seek for information as well as interest an individual places on information seeking. Jorosi (2006) established in his study that managers spend between 1 to 7 hours weekly in active information seeking.

The same table also showed that $27.7 \%$ of the respondents spend more time in the library seeking information; $23 \%$ spend more time on print materials; $22.4 \%$ spend time seeking information from superior in the office, $12 \%$ sped time on policy paper; $8.9 \%$ on colleagues in the office; only $5.8 \%$ spend time on subordinate in the office. Going by this result, it can be implied that the respondents spent time on the sources they attached importance to and the sources they are conversant with. Although Jorosi (2006) finds out in his study, that managers spend time, seeking information on customer and competitive information. The disparity in this finding can be attributed to the fact that information seeking can vary from environment to environment, as well as factors that influences such information seeking.

In order to get answer the questions posed to senior non-academic staff on challenges they face while seeking information, the respondents were asked to choose as many that applied to their situations. Table 4 has this information.

Table 4: Challenges Faced by Senior Non-academic Staff During Information Seeking and Use

\begin{tabular}{|c|l|c|c|c|c|c|c|}
\hline S/N & \multicolumn{1}{|c|}{ STATEMENT } & SA & $\mathbf{A}$ & $\mathbf{D}$ & $\mathbf{S D}$ & MEAN & STD.D \\
\hline 1 & Inadequate information retrieval & 427 & 349 & 204 & 227 & 2.67 & 1.25 \\
& technique/skills & $(33.6)$ & $(27.5)$ & $(16.1)$ & $(17.8)$ & & \\
\hline 2 & Inadequate time to seek for information & 282 & 421 & 348 & 140 & 2.55 & 1.12 \\
& & $(22.3)$ & $(33.1)$ & $(27.5)$ & $(11.7)$ & & \\
\hline 3 & Lack of awareness about where to obtain & 260 & 478 & 297 & 172 & 2.55 & 1.11 \\
& information & $(20.4)$ & $(37.6)$ & $(23.4)$ & $(13.5)$ & & \\
\hline 4 & Lack of access to information & 347 & 320 & 324 & 193 & 2.51 & 1.23 \\
& & $(27.3)$ & $(25.2)$ & $(25.6)$ & $(15.2)$ & & \\
\hline 5 & Lack of access to the internet resources & $\begin{array}{c}196 \\
(15.5)\end{array}$ & $\begin{array}{c}535 \\
(42.1)\end{array}$ & $\begin{array}{c}233 \\
(18.3)\end{array}$ & $\begin{array}{c}237 \\
(18.6)\end{array}$ & 2.44 & 1.12 \\
\hline 6 & Information sources are so far located & $\begin{array}{c}214 \\
(16.7)\end{array}$ & $\begin{array}{c}543 \\
(42.9)\end{array}$ & $\begin{array}{c}218 \\
(17.2)\end{array}$ & $\begin{array}{c}169 \\
(13.3)\end{array}$ & 2.43 & 1.20 \\
\hline 7 & Information is scattered in too many & 257 & 362 & 364 & 224 & 2.42 & 1.14 \\
\hline
\end{tabular}




\begin{tabular}{|c|l|c|c|c|c|c|c|}
\hline & Sources & $(20.3)$ & $(28.5)$ & $(28.7)$ & $(17.6)$ & \\
\hline 8 & Some of the information materials are & 211 & 445 & 334 & 188 & 2.39 & 1.14 \\
& old. & $(16.5)$ & $(35.1)$ & $(26.4)$ & $(14.8)$ & \\
\hline 9 & Information is not reliable & 274 & 222 & 438 & 203 & 2.24 & 1.25 \\
& & $(21.6)$ & $(17.4)$ & $(34.6)$ & $(16.0)$ & \\
\hline 10 & Information is sometimes not timely & 264 & 87 & 404 & 253 & 1.87 & 1.39 \\
& & $(20.8)$ & $(6.8)$ & $31.8)$ & $(19.9)$ & \\
\hline
\end{tabular}

Table 4 shows that the following are the common challenges faced by the senior non-academic staff of in Nigerian universities while seeking information to improve their job performance: lack of information retrieval techniques/skills (mean $=2.67$ ), inadequate time to seek information and lack of awareness about where to obtain information (2.55) respectively.Others such as lack of access to information, lack of access to the internet, and information are so far located are not so much challenging. This finding is troubling as the former are likely to hinder effective decision making and thereby affect job performance output. This result collaborates with Taylor (1990) who noted constraints as either with the stock or due to the user's own inability to access information. Bardford (1997) also argued that the growing availability of information, especially from electronic source, offers both potential and problems for the information user. Also Yousefi (2007) and Spurgin (2008), found out in their studies that the emergence of new information environments, sources and channels, especially the World Wide Web, regardless of the advantages, has brought new challenges and problems Hence, Fourie and Bothma (2007) stressed that an individual's ability to access, retrieve, interpret and use information is a key ingredient in achieving success.

\section{Testing of the Hypothesis}

Hypothesis one: There is no significant difference in information needs of senior non-academic staff in Various Types of Nigerian Universities (Federal, State and Private).

In order to ascertain the difference in information needs of senior non-academic staff in three types of universities in Nigeria, the null hypothesis which states that there is no significant difference in information needs of senior non-academic staff in various types of Nigerian universities was tested. This is presented in table $5 \mathrm{aa}$ and $5 \mathrm{~b}$.

Table 5a: Difference in Information Needs of Senior Non-Academic Staff

\begin{tabular}{|l|l|l|l|}
\hline University Type & N & Mean & Std. D \\
\hline Federal & 597 & 52.82 & 11.89 \\
\hline State & 331 & 51.92 & 12.27 \\
\hline Private & 339 & 51.64 & 12.72 \\
\hline Total/average & 1270 & 52.27 & 12.22 \\
\hline
\end{tabular}

Table 5a above shows that the senior non-academic staff in the Federal universities have the highest mean score for identification of information needs (52.82). This is closely followed by those in State universities (51.92), while those in private universities have the least mean score (51.64). Table 5b below shows the significant status of this difference.

Table 5b: Summary of one-way Analysis of Variance (ANOVA) on Information Needs

identification of information need
\begin{tabular}{|l|r|r|r|r|r|}
\hline & \multicolumn{1}{|c|}{ Sum of } & \multicolumn{1}{|c|}{ df } & Mean Square & F & Sig. \\
\hline Between Groups & 355.947 & 2 & 177.973 & 1.192 & .304 \\
Within Groups & 189096.1 & 1267 & 149.247 & & \\
Total & 189452.0 & 1269 & & & \\
\hline
\end{tabular}

Table $5 \mathrm{~b}$ shows that there is no significant difference among senior non-academic staff in federal, state and private universities in their level of identification of their information needs $\left(\mathrm{F}_{(2,1267)}=1.19 ; \mathrm{P}>0.05\right)$. Therefore, the null hypothesis is accepted.This implies that senior non-academic staff in Nigerian universities has the same level of information needs as regards to their job activities. 


\section{Conclusion}

The goal of this study was to find out the information needs and seeking behaviour of senior nonacademic in Nigerian universities. From the analysis of result as discussed indicated that information needs of senior non-academic staff in Nigerian universities differ based on their different job roles, and they seek information from different sources. While inadequate information retrieval techniques/skills, inadequate time to seek information and lack of awareness about where to obtain information were the major challenge senior nonacademic staff faced when seeking information.

The study recommend thus that information manager/librarians should establish information literacy program to senior -non-academic staff of the university, provide current awareness services and selective dissemination of information to senior non-academic staff in order to motivate them seek information to enhance their knowledge bank for effective and efficient work productivity.

\section{References}

[1] Agarwal, N.K., Xu, Y.C. and Poo, D.C.C. (2011). "A Context-Based Investigation into Source Use by Information Seekers". Journal of the American Society for Information Science and Technology, 62(6): 1087 - 1104.

[2] Almutairi, H. (2011). "Factors Affecting the Information Behaviours in the Kuwaiti Civil Services: A Relational Model". Information Research.http://informationr.net/ir/16-2/paper477.html Retrieved September 15th, 2011.

[3] Alwis, G.de., Majid, S. and Chaudhry, A.S. (2006). "Transformation in Managers' Information Seeking Behaviour: A Review of the Literature". Journal of Information Science, 32(4): $362-377$.

[4] Bassey, S.U. and Akpan, J. (2010). "Achievement Motivation Among University Managers and Institutional Effectiveness in Selected Nigerian Universities". Review of Higher Education in Africa, 2(1).

[5] Belkin, N.J., Brooks, H.M. \& Oddy, R.N. (1982). “ASK for Information Retrieval”. Journal of Documentation, 38(2): 61-71.

[6] Bhatti, R. (2009). "Information Needs and Information-Seeking Behavior of Faculty Members at the Islamia University of Bahawalpur”. Library Philosophy and Practice. Available at http://www.unlib.unl.edu. Retrieved February 14, 2011.

[7] Barford, J.A. (1997). Balance or Bias? Information/selection for the Researcher. Internet Research, 7(1): 53 - 58.

[8] Bradley, C. (2009). "Campus Disconnect: Academic Libraries and the Information Needs, Skills, and Behaviours of Non-Teaching University Staff". Available at www.ala.or/acrl/sites. Retrieved January $4^{\text {th }}, 2012$.

[9] Bystrom, K. (2006). "Information Activities in Work Tasks". In K.E. Fisher, S. Erdelez, \& L. McKechnie (Eds.), Theories of Information Behaviour. Pp174 - 178.

[10] Dervin, B. and Nilan, M. (1986). "Information Needs and Uses". Annual Review of Science and Technology, 21: 3-32.

[11] Fiedler, A.M; Lash, P.B.; Wong, R.M. and Tiani, T. (2006). "The Impact of Individual Employee Differences on Information Seeking in Today's Information Rich Work Environment". Available at www.Irs.org/documents/field_stats/informationseeking_spanish_2007. Retrieved April 18, 2011.

[12] Fourie, J. and Bothma, T. (2007). Addressing the Digital Divide in Teaching Information Retrieval. A Theoretical View on Taking Students from ICT Access to Knowledge Sharing Open Up.

[13] Gbadamosi, B.O. (2005). "Comparative Study of Information Requirements, Seeking Strategies and Utilization of Educational Administrators and Medical Doctors in Oyo State, Nigeria". Owena Journal of Library and Information Science, 2(1): 10 - 24.

[14] Ikoja-Odongo, R. and Mostert, J. (2006). "Information Seeking Behavior: A Conceptual Framework". South African Journal of Library and Information Science, 72(3): $145-158$.

[15] Jarvelin, K. and Wilson, T.D. (2003). "On Conceptual Models for Information Seeking and Retrieval Research". Information Research, 9(1) paper 163. Available at http://InformationR.net/iv/9-1/paper163. Retrieved December 3 ${ }^{\text {rd }}, 2011$.

[16] Jorosi, B.N. (2006). "The Information Needs and Information Seeking Behaviours of SME Managers in Bostwana". Libri, 56: 97 107.

[17] Kuhlthau, C.C. (1994). Seeking Meaning: A Process Approach to Library and Information Services. Norwood, N.J.: Ablex.

[18] Patitungkho, K. and Deshpande, N.J. (2005). "Information Seeking Behaviour of Faculty Members of Rajabhat Universities in Bangkok". Weblogy, 2(4). Available at http://www.weblogy.ir/2005/v2n4/a20.html. Retrieved March 3, 2011.

[19] Pettigrew, K.E. (1996). “ Modeling the Information Seeking of Professionals”. Library Quarterly, 66(2): 161-193.

[20] Popoola, S.O. (2006). "Information Accessibility and Utilization as Factors Influencing Decision-Making of Managers in Commercial Banks in Nigeria". Available at www.indianjournals.com/ijor.aspx? Retrieved December 8, 2011.

[21] Smerek, R. \& Peterson, M. (1993). Examining Herzberg's Theory: Improving Job Satisfaction Among Non-Academic Employees at a University. Research in Higher Education, 48(2): 229 - 250.

[22] Tackie, S.N.B. and Adams, M. (2007). "Information Needs and Seeking Behavior of Engineers in Ghana: A Case Study of the Volta River Authority". African Journal of Library, Archives \& Information Science, 17(2): 69 - 78.

[23] Taylor, D.C. (1990). Undergraduates' Use of Periodicals: Implications for Library Reference Work". Reference Librarian, 27/28: $51-56$.

[24] Wilkins, J.L.H. and Leckie, G.J. (1997). "University Professional and Managerial Staff: Information Needs and Seeking”. http:// Wu, I-Chin, (2011). "Toward Supporting Information-Seeking and Retrieval Activities Based on Evolving Topic-Needs". Journal of Documentation, 67(3): $525-559$.

[25] Yan, Y. and Davison, R.M. (2011). "Using Decision Support Systems in Chinese Enterprises: A Study of Managerial Information Behaviour". Information Development, 27(1): 15.

[26] Yousefi, S. (2007). Information and Information Seeking Behaviour of Professionals at an Iranian Company. Library Student Journal. http://www.librarystudentjournal.org/indexphp/isj/article. Retrieved August 1, 2011. 